\title{
Germination response of Amaranthus caudatus L. to soil types and environmental conditions
}

\author{
Muhali Olaide Jimoh ${ }^{1}$, Anthony Jide Afolayan ${ }^{1 *}$ and Francis Bayo Lewu ${ }^{2}$ \\ ${ }^{1}$ Medicinal Plants and Economic Development (MPED) Research Centre, Department of Botany, \\ University of Fort Hare, Alice 5700, South Africa; moajay006@gmail.com, aafolayan@ufh.ac.za \\ 2 Department of Agriculture, Cape Peninsula University of Technology, Wellington Campus, Wel- \\ lington 7654, Cape Town, South Africa; LewuF@cput.ac.za \\ *Corresponding author: aafolayan@ufh.ac.za
}

Jimoh M. O., Afolayan A. J., Lewu F. B. (2019): Germination response of Amaranthus caudatus L. to soil types and environmental conditions. - Thaiszia J. Bot. 29 (1): 085-100.

Abstract: Little attention is being paid to Amaranthus caudatus in the Eastern Cape Province and other parts of South Africa as a vegetable that has huge potentials in bridging nutritional gap between the rich and the poor. This work investigated germination response of the plant to environmental conditions and variation in its germination characteristics at various depths in different soil types with the intent of complementing limited data available on the general agronomy of the species. At the end of the study, the highest germination was recorded at $25{ }^{\circ} \mathrm{C}$ and under continuous dark conditions, although the seeds germinated well under a wide range of temperatures and other photoperiods. The species germinated under all seeding depths considered, though late emergence was observed at depths below $2 \mathrm{~cm}$. In addition, a significant $(P<0.05)$ interaction in pattern of germination was observed in three out of the five soil types tested, whereas the control (unfractionated) soil showed a highly significant $(\mathrm{P}<0.01)$ interaction with the silt clay loam and loam soil. This overlapping interaction further confirmed that the plant has wide surviving capabilities in various soils and environmental conditions, hence, for optimum seedling emergence, it is recommended that $A$. caudatus be planted in a loamy soil maintained at $25{ }^{\circ} \mathrm{C}$ in a continuous dark environment.

Keywords: Alternating temperatures, Amaranthus caudatus, germination characteristics, photoperiods, sowing depth 


\section{Introduction}

Information on phenology of seed germination reveals that each species follows a characteristic germination pattern in every season. Germination season is limited for many species. Some species have the capacity to germinate all through seasons while some species tend to acquire traits adapted to their habitats to meet germination requirements (Olff et al. 1994; Meyer et al. 1997). Therefore, adequate knowledge of germination characteristics is important due to its immense contribution to the understanding of some key biological concepts which include speciation, reproductive strategies, physiological processes and mechanisms of adaptation to the environment (Baskin \& Baskin 2001; Baskin et al. 2001).

The process of germination is critical in the life of a seed. It is characterised by cellular and molecular events in a complex but gradual manner which make estimation of the beginning and end of germination difficult (Ranal \& Santana 2006). Generally, germination begins with imbibition, followed by the activation process and intra-seminal growth, resulting in protrusion of the embryo which completes the germination process (Labouriau 1983). However, precision in determining the exact time germination occurs in plant species has been subject of contradictions among researchers due to under or overestimation of germination capacities of plants, thereby making acceptability of results difficult. Hence, many researchers adopted germinability and other related terms as a consensus in measuring germination (Labouriau 1983; Ranal \& Santana 2006).

In his paper on history of germination, Evenari (1980) reported that Theophrastus (c372-287 BC) had listed factors controlling seed germination characteristics to include: food reserved in seed embryo, environment under which seed matures, climatic factors, presence of growth inhibitor, thickness of seed coats and seed age. However, a combination of environmental factors such as light, temperature and soil conditions also controls seed germination (Kambizi et al. 2006; Lewu et al. 2010; Chauhan \& Johnson 2008; Torra et al. 2016). Thus, requirements for seedling emergence and germination can be used to characterize the prevalence and adaptability range of a species (Chauhan et al. 2006; Chauhan \& Johnson 2009).

Recent focus on Amaranthus species resides in the fact that they have a great amount of genetic diversity, phenotypic plasticity, they are extremely adaptable to adverse growing conditions, they resist heat and drought, have no major disease problem, and are among the easiest of plants to grow in agriculturally marginal lands (Rastogi \& Shukla 2013). In spite of the above, data on cultivation statistics of Amaranthus is limited in South Africa (van Rensburg 2014) due to 
inadequate research and underestimation of its nutritional values. An empirical study on the production requirements of the species, especially under small scale system, is therefore imperative.

Amaranthus caudatus L. is an annual flowering plant with red pendant inflorescence. The red inflorescence has been attributed to the presence of betacyanin pigment (Cai \& Corke 1999). Many parts of the plant are edible and are used as a source of medicine in Africa, India, South America and other parts of the world (Gupta et al. 2004; Idris et al. 2017; Peter \& Gandhi 2017). A. caudatus has been reported in several publications for its nutritional, phyto-medicinal and ethnobotanical purposes. In South Africa and Swaziland, the ash of the plant is used either alone or mixed with an equal quantity of powdered tobacco for making snuff and the leaf is used as an abortifacient and in pulmonary condition (Edward 1978; Jimoh et al. 2018). The foliage is used to reduce hemorrhea, diarrhoea, and to treat ulcerated wounds. The dried flowers are used as tea and in contraception and excessive menses while the boiled leaves are used in swellings and in stomach upset (Kufer \& Heinrich 2003). In ayurvedic medicine system of India, $A$. caudatus is used to treat a number of ailments, namely goitre, urinary trouble, piles, pulmonary disorder, etc. The leaves are used as tea for blood purification and as diuretic (Chopra \& Kanwar 1991; Gupta et al. 2004). The seeds could inhibit the growth of different plant pathogenic fungi at much low doses and other chitin binding protein. They also show activity to gram positive bacteria (Rastogi \& Shukla 2013).

The dearth of information on effects of soil types on propagation of $A$. caudatus in the Eastern Cape Province may not be unconnected to its small seeds size, little cultivation data and a lack of appropriate crop protection techniques, despite being a promising plant for development as an agricultural crop in South Africa (van Rensburg 2014). It is therefore pertinent to investigate the germination dynamics of $A$. caudatus seeds in order to examine conditions controlling their germination such as photoperiod, alternating temperatures and sowing depths. This will assist to document adequate information on germination requirements of the plant with respect to the Eastern Cape condition as the species tend to acquire traits adapted to their habitats to meet germination requirements (OIff et al. 1994; Meyer et al. 1997).

Hence, the core objective of this work was to investigate germination requirements of $A$. caudatus in the Eastern Cape where it is regarded as a wild plant under conditions such as alternating temperatures and photoperiods and to examine variation in its seedling emergence in different soil types with the intent of augmenting limited data available on the plant. 


\section{Materials and methods}

\section{Study area}

Light and temperature ranges. Both light and temperature experiments were carried out in Medicinal Plants and Economic Development research laboratories, Botany Department, University of Fort Hare, Alice campus. Alice town is located within coordinates $32^{\circ} 47^{\prime} \mathrm{S}, 26^{\circ} 50^{\prime} \mathrm{E}$; altitude $535 \mathrm{~m}$ a.s.l., in the Eastern Cape Province of South Africa.

Sowing depth determination. This was conducted in the greenhouse, sited on the roof of Botany Department building, University of Fort Hare.

\section{Collection of materials}

Seed collection. Mature seeds of $A$. caudatus were collected from seed bank at the Medicinal Plants and Economic Development (MPED) Research Centre, Botany Department, Faculty of Science and Agriculture, University of Fort Hare and were tested for viability.

Soil collection. Top soil for the experiment was collected from the University of Fort Hare's Research Farm Unit ( $\left.32^{\circ} 47^{\prime} \mathrm{S}, 26^{\circ} 53^{\prime} \mathrm{E}\right)$, situated $5 \mathrm{~km}$ east of Alice in the Eastern Cape, South Africa. The soil sample was transferred subsequently to the green house for further treatments.

Experimental soil formulation. Top soil collected from school farm was air dried in the green house and sieved into various particle sizes of clay, sand and silt using iron sieves of designated mesh sizes ranging from 0.25-2 mm. Experimental soil was then formulated by mixing sieved soil particles in proportions proposed by the United States Department of Agriculture's (USDA) soil texture triangle as shown in Table 1.

Tab. 1. Experimental soil formulation in proportions recommended by soil texture triangle technique (USDA 1951)

\begin{tabular}{lcccc}
\hline $\mathbf{S / N}$ & Soil types & \% Sand & \% Silt & \% Clay \\
\hline $\mathbf{1}$ & Sandy Clay Loam & 66 & 13 & 21 \\
$\mathbf{2}$ & Silty Clay Loam & 10 & 60 & 30 \\
$\mathbf{3}$ & Clayey Loam & 36 & 30 & 34 \\
$\mathbf{4}$ & Loam & 40 & 40 & 20 \\
$\mathbf{5}$ & Control soil & Unfractionated & Unfractionated & Unfractionated \\
\hline
\end{tabular}

After formulating the soils, each soil sample was heaped in cavity trays in three replicates, filled to the brim and tagged accordingly. 
Seed viability test. Seed viability was verified using tetrazolium (2, 3, 5triphenyltetrazolium chloride) and sodium hypochlorite ( $\mathrm{NaOCl}$ ) tests of seeds as proposed by Leist \& Krämer (2003) and Peters (2000). A. caudatus seeds were imbibed in water for $24 \mathrm{~h}$, cut along the margin without damaging the embryo and soaked in colourless $0.1 \%$ solution of 2,3,5-triphenyltetrazolium chloride (TTC) for $16 \mathrm{~h}$ at $25^{\circ} \mathrm{C}$ in the dark. The seeds were then removed from TTC solution, washed with distilled water and soaked in $10 \mathrm{ml}$ of $95 \%$ ethyl alcohol to permit direct observation of the embryo. This was repeated for three replicates of 50 seeds.

Seed weight. Seed weight was determined by calculating the mean weight of a seed after weighing 100 seeds in three replicates on an analytical balance.

Seed germination trial. Germination trials were conducted by placing 50 seeds each in (9-cm diameter) sterile Petri dishes lined with two Whatman No. 1 filter papers and moistened with $3 \mathrm{ml}$ distilled water to ensure the filter papers were adequately moistened for seed germination. Treatments were arranged in three replicates of 50 seeds each and inspected for 14 days. On daily basis, germinated seeds were counted and removed from the petri dishes. Emergence of radicle was used as confirmation of germination.

Effect of light. The effect of photoperiodism on germination was investigated under continuous light, continuous darkness and alternating light and dark in a controlled atmosphere. For continuous darkness treatment, Petri dishes lined with two Whatman No. 1 filter papers and moistened with $3 \mathrm{ml}$ distilled water were wrapped with three layers of aluminium foil and kept in the dark room for 14 days. The dishes were carefully opened and observed under green safe light every day to count number of seeds germinated. Petri dishes for light treatment were exposed to continuous illumination supplied by white fluorescent tubes

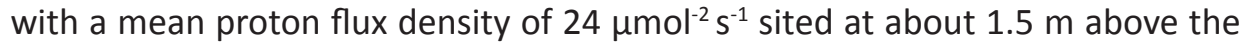
dishes to supply red light for germination. For alternating light and darkness treatment, Petri dishes were placed in a room that has access to alternating photoperiod as dictated by weather condition. For each treatment, 50 seeds were placed in each dish in triplicates and $10 \mathrm{~mL}$ of distilled water was added when necessary.

Effect of temperature. This was examined by placing 50 seeds of $A$. caudatus in Petri dishes lined with a double sheet of Whatman No. 1 filter paper and moistened with $3 \mathrm{ml}$ of distilled water. The dishes were arranged in 3 replicates and placed in incubators set at $10,15,20,25,30,35$ and $40^{\circ} \mathrm{C}$ respectively. Germination count was taken every day for 14 days and seeds with protruded radicles were considered germinated and subsequently removed from the Petri dishes. 
Effects of sowing depths and soil types on germination. This was investigated by placing 5 seeds in each $3 \mathrm{~cm}$ diameter hole of a $65 \times 100 \mathrm{~cm}^{2}$ cavity trays at different sowing depths of 0 (soil surface), 1, 2, 3, 4 and $5 \mathrm{~cm}$ in 3 replicates. The trays were filled with different soil types formulated in accordance with USDA (1951) recommendations except for the control (unfractionated) soil which was used as gotten from the farm. The five soil types used were: control (unfractionated), sandy clay loam, silty clay loam, clayey loam and loam. Trays were irrigated daily, and germination count was recorded for 14 days. Seedling emergence was monitored daily and used as the criterion for germination.

\section{Measuring germination dynamics (Germinability)}

\section{i) Mean germination time - MGT ( $\bar{T})$}

This was calculated as the weighted mean of the germination time as proposed by Haberlandt in 1875 (Labouriau 1983). Total number of seeds germinated during the period of data collection was used as weight. The use of the weighted mean in estimating MGT is indispensable, since it takes into consideration how long it takes for different number of seeds to germinate.

$$
\overline{\mathrm{T}}=\frac{\sum n i t i}{\sum n i}
$$

Where;

$\overline{\mathbf{T}}=$ mean germination time

$n_{i}=$ number of seeds germinated in the time $i$ corresponding to the $i^{\text {th }}$ observation $t_{i}=$ time from the start of the experiment to the $i^{i^{\text {th }}}$ observation (day or hour)

\section{ii) Mean germination rate - MGR ( $\overline{\mathbf{u}})$}

This was evaluated as reciprocal of mean germination time (Ranal \& Santana 2006).

$$
\overline{\mathrm{v}}=\frac{1}{\overline{\mathrm{T}}}
$$

Where;

$\overline{\mathbf{u}}=$ mean germination rate

$\overline{\mathbf{T}}=$ mean germination time 


\section{Statistical analysis}

Data from all treatments were analysed and expressed as mean \pm standard deviation (SD) of 3 replicates. For light and temperature treatments, one-way analysis of variance (ANOVA) was used to determine significant differences in germination parameters and the effect of both conditions on germination percentage; while Pearson correlation analysis was used to compare relationship between and within seeds grown on different soil types at depths $(0,1,2,3$, 4 and $5 \mathrm{~cm}$ ) mentioned above. In all, treatments were considered significantly different at $P<0.05$ level. Where the data showed no significant difference, a mean separation was done by comparing multiple means using the Levene's Test for Equality of Variances with the aid of Statistical Package for the Social Sciences 20 (SPSS 20) statistical package to define the general pattern of germination.

\section{Results}

\section{Seed weight and viability}

The mean weight of 50 seeds was $38.3 \mathrm{mg}$, therefore, the average weight of a seed was $0.766 \mathrm{mg}$. Out of 50 seeds (in 3 replicates) treated with $0.1 \%$ triphenyl tetrazolium chloride, a total of $94.2 \%$ were viable.

\section{Effect of light on germination over a period of 14 days}

In all light regime treatments, lowest percentage live seed emergence was recorded in continuous light; highest percent germination was recorded in continuous dark followed by alternating light and dark condition. For continuous light, continuous dark and alternating light and dark conditions, the mean percentage germination recorded were $84.00 \%, 94.67 \%, 92.00 \%$ respectively (Fig. 1). This indicates that dark condition supports germination of $A$. caudatus seeds than continuous light and alternating conditions although percentage germination was comparably high under the three conditions.

\section{Effect of Temperature on germination over a period of 14 days}

The results of the influence of temperature on the germination of $A$. caudatus are presented on Tab. 2 and Fig. 2 . The results showed that different temperatures had significant effects on germination. 


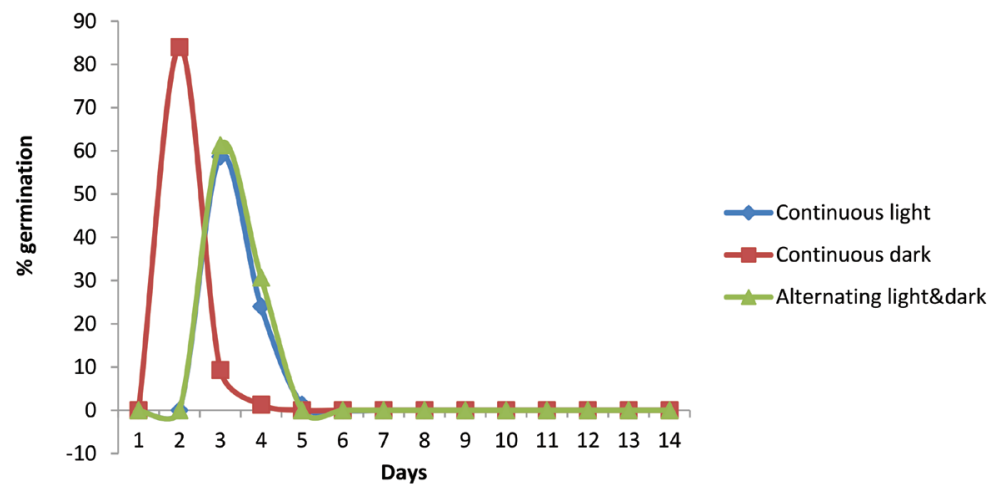

Fig. 1. Effects of light conditions on mean percentage germination of $A$. caudatus seeds over 14 days.

Tab. 2. Effect of varying temperature conditions on percentage germination of Amaranthus caudatus seeds monitored daily over 14 days

\begin{tabular}{lccccccc}
\hline Day & $\mathbf{1 0 ^ { \circ } \mathbf { C }}$ & $\mathbf{1 5 ^ { \circ } \mathbf { C }}$ & $\mathbf{2 0 ^ { \circ } \mathbf { C }}$ & $\mathbf{2 5 ^ { \circ } \mathbf { C }}$ & $\mathbf{3 0 ^ { \circ } \mathbf { C }}$ & $\mathbf{3 5 ^ { \circ } \mathbf { C }}$ & $\mathbf{4 0 ^ { \circ } \mathbf { C }}$ \\
\hline $\mathbf{0}$ & NG & NG & NG & NG & NG & NG & NG \\
$\mathbf{1}$ & NG & NG & NG & NG & $89.33 \pm 4.16$ & $85.33 \pm 3.06$ & $80.00 \pm 4.00$ \\
$\mathbf{2}$ & NG & $54.67 \pm 4.16$ & $76.00 \pm 4.00$ & $98.67 \pm 1.15$ & $1.33 \pm 1.15$ & NG & $5.33 \pm 1.15$ \\
$\mathbf{3}$ & NG & $34.67 \pm 3.06$ & $6.67 \pm 3.06$ & $1.33 \pm 1.15$ & $1.33 \pm 1.15$ & NG & $1.33 \pm 1.15$ \\
$\mathbf{4}$ & NG & $1.33 \pm 1.15$ & $2.67 \pm 1.15$ & NG & $1.33 \pm 1.15$ & NG & NG \\
$\mathbf{5}$ & NG & $2.67 \pm 1.15$ & NG & NG & NG & NG & NG \\
$\mathbf{6}$ & NG & NG & NG & NG & NG & NG & NG \\
$\mathbf{7}$ & NG & NG & NG & NG & NG & NG & NG \\
$\mathbf{8}$ & NG & NG & NG & NG & NG & NG & NG \\
$\mathbf{9}$ & NG & NG & NG & NG & NG & NG & NG \\
$\mathbf{1 0}$ & NG & NG & NG & NG & NG & NG & NG \\
$\mathbf{1 1}$ & NG & NG & NG & NG & NG & NG & NG \\
$\mathbf{1 2}$ & NG & NG & NG & NG & NG & NG & NG \\
$\mathbf{1 3}$ & NG & NG & NG & NG & NG & NG & NG \\
$\mathbf{1 4}$ & NG & NG & NG & NG & NG & NG & NG \\
\hline
\end{tabular}

Values are mean percentage germination \pm standard deviation of mean of three replicates $(n=$ 50); ( $p<0.05)$; NG: no germination

\section{Effects of sowing depths and soil types on germination}

A combined effect of soil types and burial depths on germination is illustrated in Fig. 3 and Tab. 3 below. The percentage of seed emergence was highest at $1 \mathrm{~cm}$ $(78 \%)$ and $2 \mathrm{~cm}(78.67 \%)$ of seeding depth while a sharp decline in germination was observed for other depths $(3,4$ and $5 \mathrm{~cm})$ due to limited exposure to light. There was also a reduction in seedling emergence in the control (unfractionated) 
soil at $1 \mathrm{~cm}$ below soil surface coupled with variabilities in percentage germination for different soil types. At $p<0.05$, significant difference was observed only in the clayey loam whereas for the control soil and sandy clayey loam, variability was insignificant. Silty clayey loam and loamy soils specifically showed significant difference at $p<0.01$ indicating relationship in percent seed growth performance in the two soils. Also, data from Pearson correlation analysis indicate significant correlation between sowing depth in silty clayey loam, clayey loam and loam at $p<0.05$. At $p<0.01$, there was high correlation between and within control soil, silty clayey loam and loam.

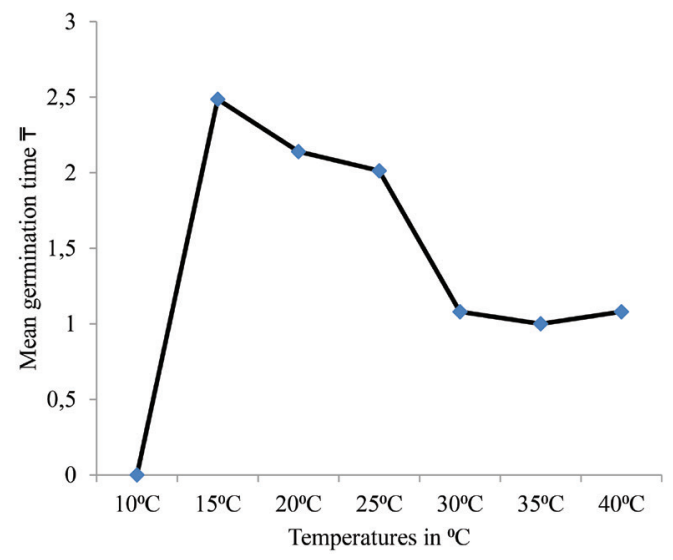

Fig. 2. Effects of varying temperature on mean germination time $(\overline{\mathrm{T}})$

Tab. 3. Interaction of sowing depths and soil types on germination

\begin{tabular}{lccccc}
\hline $\begin{array}{l}\text { Sowing } \\
\text { depth }\end{array}$ & Control soil* & Sandy clay loam & $\begin{array}{c}\text { Silty clay loam** } \\
\mathbf{a}\end{array}$ & Clayey loam**, b & Loam $^{* *}, \mathbf{a}$ \\
\hline $\mathbf{0} \mathbf{~ c m}$ & $13.33 \pm 3.21$ & $50.67 \pm 3.06$ & $15.33 \pm 9.07$ & $8.00 \pm 2.00$ & $18.00 \pm 1.73$ \\
$\mathbf{1} \mathbf{~ c m}$ & $27.33 \pm 15.04$ & $64.00 \pm 5.56$ & $60.67 \pm 1.53$ & $70.00 \pm 7.21$ & $78.00 \pm 3.00$ \\
$\mathbf{2} \mathbf{~ c m}$ & $52.00 \pm 1.73$ & $38.00 \pm 5.29$ & $52.00 \pm 2.64$ & $60.00 \pm 11.36$ & $78.67 \pm 6.51$ \\
$\mathbf{3} \mathbf{~ c m}$ & $18.00 \pm 1.00$ & $32.00 \pm 3.61$ & $19.33 \pm 4.04$ & $22.00 \pm 3.00$ & $30.00 \pm 2.64$ \\
$\mathbf{4} \mathbf{~ c m}$ & $3.33 \pm 1.15$ & $10.00 \pm 2.65$ & $4.00 \pm 1.73$ & $13.33 \pm 2.08$ & $9.33 \pm 0.58$ \\
$\mathbf{5} \mathbf{~ c m}$ & $2.00 \pm 1.00$ & $4.00 \pm 1.00$ & $2.67 \pm 1.15$ & $10.67 \pm 3.06$ & $0.67 \pm 0.58$ \\
\hline SED & 8.64 & 7.71 & 11.45 & 14.91 & 16.46 \\
\hline
\end{tabular}

$\mathrm{SED}=$ standard error of differences; *. Correlation is significant at $\mathrm{p}<0.05$ (2-tailed); **. Correlation is significant at $p<0.01$ and at $p<0.05$ (2-tailed); ${ }^{\text {a }}$. significant difference at $p<0.01$; b. significant difference at $p<0.05$ 


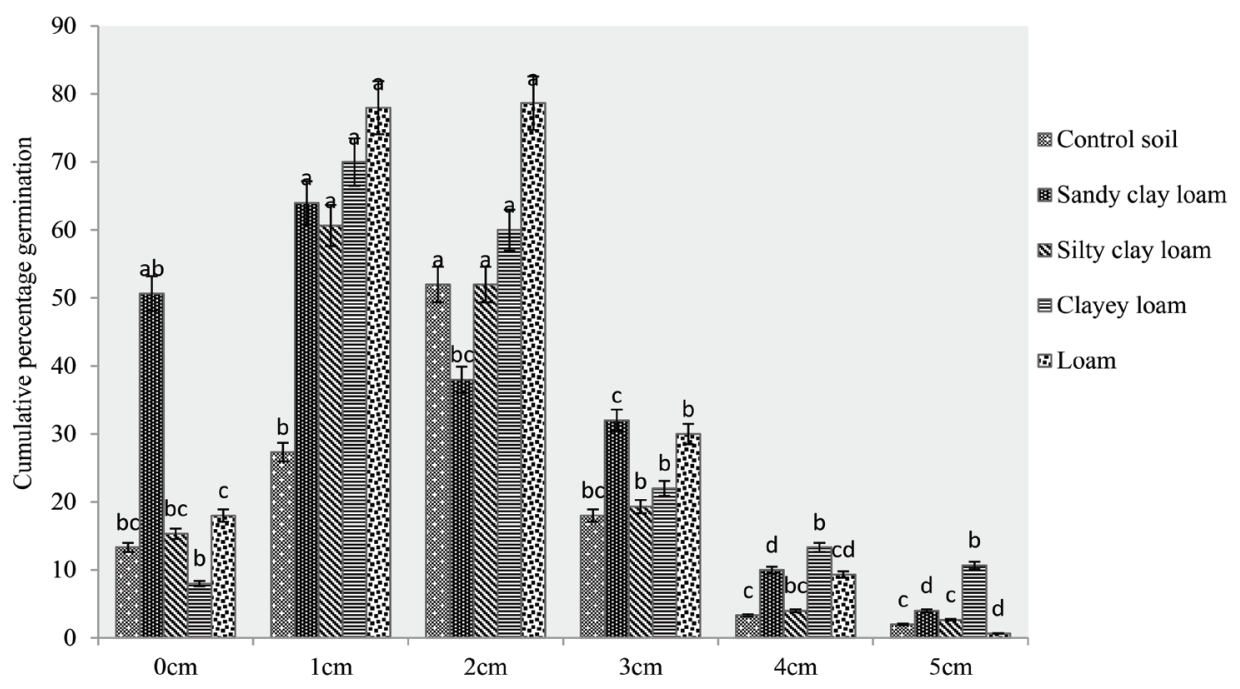

Fig. 3. Effects of sowing depth and soil types on cumulative percentage germination

\section{Discussion}

The end of germination process is marked by intra-seminal protrusion of the embryo, after which seedling growth commences. It is difficult to measure germination precisely; the only stage that can be measured fairly is its end when radicle emerges (Ranal \& Santana 2006). In his report, Nerson (2007) described germinability of a seed sample as the percentage or proportion of seeds that completes germination under experimental condition, value(s) of which may be subjected to further statistical analysis. The $94.2 \%$ viability reported in the tetrazolium chloride test was an indication that seeds used for this study were viable.

The effect of light on amaranth seed germination may be overridden by warmer temperatures occasioned by seasonal fluctuations although light is a crucial factor for germination in some amaranth plants (Aufhammer et al. 1998; Gallagher \& Cardina 1998). Continuous light condition has been reported to have inhibitory effects on the germination of some species particularly at temperature less than $25^{\circ} \mathrm{C}$ (Aufhammer et al. 1998) although, this effect may be reversed (Tiryaki \& Keles 2012). Considering that at least $84 \%$ germination was recorded in this species, it can be argued that light condition may not significantly affect germination in $A$. caudatus; but continuous dark condition is proven to be more favourable. 
A substantial germination counts were recorded within temperature ranges of $15-40{ }^{\circ} \mathrm{C}$ whereas no seed germinated at $10{ }^{\circ} \mathrm{C}$ although germination may be induced at this temperature by osmotic priming (Tiryaki 2009). The highest germination counts recorded at $25{ }^{\circ} \mathrm{C}$ suggests that $25{ }^{\circ} \mathrm{C}$ was the optimum temperature. Also, at 15 and $30{ }^{\circ} \mathrm{C}$ respectively, equal cumulative percentage germination was recorded, indicating that both temperatures had similar effect on germination. In addition, the accelerated seed germination recorded the second day at high temperatures $\left(30,35\right.$ and $\left.40{ }^{\circ} \mathrm{C}\right)$ corroborates early findings of (Gutterman et al. 1992) that germination of $A$. caudatus seeds was most rapid at $35^{\circ} \mathrm{C}$ unlike in other species of the genus (such as $A$. palmeri) where secondary dormancy was induced when seeds were exposed to high temperature (Jha et al. 2010). It may be added that the plant's seed embryo is tolerant to heat as germination occurred at higher temperature; a temperature at which growth may cease although over exposure to these temperatures may eventually kill plant (Guo \& Al-Khatib 2003; Olatunji \& Afolayan 2019).

This study also revealed that sowing depths and soil types affected emergence of $A$. caudatus seedlings (Tab. 3, Fig. 3). At the surface level, low germination was recorded in all soils except for sandy clay loam which supported more germination than any other soil type examined. This may be connected with its loose particle arrangement and or big particle size that compares or slightly bigger than amaranth seed, thereby enhancing the contact of seeds with the soil. This agrees with the earlier submission that species responds to soil particle size gradient during germination (Keddy \& Constabel 1986; Moskova 2012; Omami et al. 1999). Lower germination rate in other soil types for seeds placed on the soil surface may be caused by poor soil-seed contact or lower soil water potential close to the seed surface (Ghorbani et al. 1999). Besides, exposure to light at the surface has been reported to have inhibitory effect on amaranth seed germination at temperatures below $25^{\circ} \mathrm{C}$; thereby affecting emergence of amaranth seeds on soil surface when temperature is below $25{ }^{\circ} \mathrm{C}$ even if sufficient water is available (Aufhammer et al. 1998; Tiryaki \& Keles 2012).

Moreover, limited exposure to light resulted in a sharp decline in germination for seeds buried at depths 3,4 and $5 \mathrm{~cm}$ due, although, higher temperature coupled with variability in seasonal seed dormancy may override this effect (Gallagher \& Cardina 1998; Bae \& Choi 2008; Adegbaju et al. 2018). Bavec \& Mlakar (2002) had earlier observed highest percentage of live seed emergence in $A$. caudatus when sown in loamy soil with three other amaranth species at depth of $15 \mathrm{~mm}$ and temperature above $21^{\circ} \mathrm{C}$. This agrees with the result of this experiment where highest seedling emergence was observed at $1 \mathrm{~cm}$ depth for all soil types except in the unfractionated soil. Reduction in seedling emergence 
observed in the control (unfractionated) soil at $1 \mathrm{~cm}$ below soil surface may not be unconnected with surface hardening or compaction affecting water permeation into the soil thereby increasing mechanical resistance to emerging plumule and radicle penetration (Bassett et al. 2005; Smith et al. 2001; Soyelu et al. 2001).

\section{Conclusion}

Environmental factors such as light and temperature usually cause cyclic changes in seed dormancy and contribute in different degrees depending on length of exposure of seeds to the conditions or variation in the amount available. Although, it has been reported that placing seeds of some amaranth species at depths below $2.5 \mathrm{~cm}$ could make the seeds latent over a period of 3-12 months and as such, no germination will take place. This work reported germination in A. caudatus at deeper depths in different soil types used (most successfully in loamy soil), although percentage of germination declined sharply at depths below $2 \mathrm{~cm}$. The seeds germinated excellently under a wide range of temperature and varying light conditions with highest germination recorded under $25{ }^{\circ} \mathrm{C}$ and continuous dark treatment. Therefore for optimum seedling emergence, it is recommended that $A$. caudatus be planted in a loamy soil maintained at $25^{\circ} \mathrm{C}$ in a continuous dark environment.

\section{References}

Adegbaju O. D., Otunola G. A., Afolayan A. J. (2018): Effect of temperature, light and sowing depth on seed germination of Celosia argentea L. - Asian J. PI. Sci. 17(1): 47-55. DOI: 10.3923/ajps.2018.47.55

Aufhammer W., Czuczorova D., Kaul H. P., Kruse M. (1998): Germination of grain amaranth (Amaranthus hypochondriacus $\mathrm{x}$ A. hybridus): effects of seed quality, temperature, light, and pesticides. - Eur. J. Agron. 8(1-2): 127-135. https://doi.org/10.1016/S1161-0301(97)00049-X

Bae G. \& Choi G. (2008): Decoding of light signals by plant phytochromes and their interacting proteins. -Annu. Rev. Plant. Biol. 59: 281-311. doi: 10.1146/ annurev.arplant.59.032607.092859

Baskin C. C. \& Baskin J. M. (2001): Seeds: Ecology, biogeography, and evolution of dormancy and germination. - Academic Press, pp. 1-4.

Baskin C. C., Milberg P., Anderson L., Baskin J. M. (2001): Seed dormancybreaking and germination requirements of Drosera anglica, an insectivorous 
species of the Northern Hemisphere. - Acta Oecol. 12: 1-8. https://doi. org/10.1016/S1146-609X(00)01093-6

Bassett I. E., Simcock R. C., Mitchell N. D. (2005): Consequences of soil compaction for seedling establishment: Implications for natural regeneration and restoration. - Austral Ecol. 30(8): 827-833. https://doi.org/10.1111/j.14429993.2005.01525.x

Bavec F. \& Mlakar S. G. (2002): Effects of soil and climatic conditions on emergence of grain amaranths. - Eur. J. Agron. 17(2): 93-103. https://doi.org/10.1016/ S1161-0301(01)00144-7

Cai Y. \& Corke H. (1999): Amaranthus betacyanin pigments applied model food systems. - J. Food Sci. 64(5): 869-873. https://doi. org/10.1111/j.1365-2621.1999.tb15930.x

Chauhan B. S. \& Johnson D. E. (2009): Seed germination and seedling emergence of Synedrella (Synedrella nodiflora) in a tropical environment. - Weed Sci. 57(1): 36-42. DOI: 10.1614/WS-08-015.1

Chauhan B. S., Gill G., Preston C. (2006): Factors affecting seed germination of annual sowthistle (Sonchus oleraceus) in southern Australia. - Weed Sci. 54(5): 854-860. https://doi.org/10.1614/WS-06-047R.1

Chauhan B. S. \& Johnson D. E. (2008): Influence of environmental factors on seed germination and seedling emergence of eclipta (Eclipta prostrata) in a tropical environment. - Weed Sci. 56(3): 383-388. https://doi.org/10.1614/ WS-07-154.1

Chopra S. L. \& Kanwar J. S. (1991): Analytical agricultural chemistry. - Kalyani Publications, New Delhi.

Edward S. A. (1978): Medicinal plants of South Africa. - Michigan Publication. Inc.

Evenari M. (1980): The history of germination research and the lesson it contains for today. - Israel J. Bot. 29: 4-21.

Gallagher R. S. \& Cardina J. (1998): Phytochrome-mediated Amaranthus germination. I: Effect of seed burial and germination temperature. - Weed Sci. 46(1): 48-52.

Ghorbani R., Seel W., Leiferr C. (1999): Effects of environmental factors on germination and emergence of Amaranthus retroflexus. - Weed Sci. 47(5): 505-510.

Gou P. \& Al-Khatib K. (2003): Temperature effects on germination and growth of Redroot pigweed (Amaranthus retroflexus), Palmer amaranth (A. palmeri), and Common waterhemp (A. rudis). - Weed Sci. 51(6): 869-875. https://doi. org/10.1614/P2002-127 
Gupta A. K., Sharma M., Tandon N. (2004): Reviews on Indian Medicinal Plants: Vol. 2 - New Delhi, India. - Indian Council of Medical Research.

Gutterman Y., Corbineau F., Come D. (1992): Interrelated effects of temperature, light and oxygen on Amaranthus caudatus L. seed germination. - Weed Res. 32(2): 111-117. https://doi.org/10.1111/j.1365-3180.1992.tb01868.x

Idris O. A., Wintola O. A., Afolayan A. J. (2017): Phytochemical and antioxidant activities of Rumex crispus L. in treatment of gastrointestinal helminths in Eastern Cape Province, South Africa. - Asian Pacific J. Trop. Biomed. 7(12): 1071-1078. DOI: 10.1016/j.apjtb.2017.10.008

Jha P., Norsworthy J. K., Riley M. B., Bridges jr. W. (2010): Annual changes in temperature and light requirements for germination of Palmer amaranth (Amaranthus palmeri) seeds retrieved from soil. - Weed Sci. 58(4): 426-432. https://doi.org/10.1614/WS-D-09-00038.1

Jimoh M. O., Afolayan A. J., Lewu F. B. (2018): Suitability of Amaranthus species for alleviating human dietary deficiencies. - S. African J. Bot. 115: 65-73. https://doi.org/10.1016/j.sajb.2018.01.004

Kambizi L., Adebola P. O., Afolayan A. J. (2006): Effects of temperature, prechilling and light on seed germination of Withania somnifera; a high value medicinal plant. - S. African J. Bot. 72(1): 11-14. https://doi.org/10.1016/j. sajb.2005.03.001

Keddy P. A. \& Constabel P. (1986): Germination of ten shoreline plants in relation to seed size, soil particle size and water level: An experimental study. - J. Ecol. 74(1): 133-141. DOI: 10.2307/2260354

Kufer J. \& Heinrich M. (2003): South American Medicinal Plants. Botany, Remedial Properties and General Use. - J. Plant Physiol. 160(11): 1415.

Labouriau L. G. (1983): The germination of the seeds. - Organization of American States. Regional Program of Scientific and Technological. - Ser. Biol. Monograph, pp. 24.

Leist N. \& Krämer S. (2003): ISTA Working sheets on tetrazolium testing: Volume I. Agricultural, vegetable and horticultural species (1st edition). pp. 176.

Lewu F. B., Grierson D. S., Afolayan A. J. (2010): Influences of seed source, pre-chilling, light and temperature on the germination of South African Pelargonium sidoides. - J. Agr. Sci. Tech. 4(3): 18-23.

Meyer S. E., Allen P. S., Beckstead J. (1997): Seed germination regulation in Bromus tectorum (Poaceae) and its ecological significance. - Oikos 78(3): 475-485. DOI: 10.2307/3545609

Moskova C. (2012): Influence of depth placement and duration of stay in the soil of Amaranthus species seeds on rest and germination. - Sci. Pap. Ser. A. Agron. 55: 306-309. 
Nerson H. (2007): Seed production and germinability of cucurbit crops. - Seed Science Biotechnology. 1: 1-10.

Olatunji T. L. \& Afolayan A. J. (2019): Variability in seed germination characteristics of Capsicum annuum L. and Capsicum frutescens L. - Pakistan J. Bot. 51(2): 561-565. DOI: 10.30848/PJB2019-2(18)

Olff H., Berendse F., de Visser W. (1994). Changes in nitrogen mineralization, tissue nutrient concentrations and biomass compartmentation after cessation of fertiliser application to mown grassland. - J Ecol. 82(3): 611620. DOI: $10.2307 / 2261268$

Omami E. N., Haigh A. M., Medd R. W., Nicol H. I. (1999): Changes in germinability, dormancy and viability of Amaranthus retroflexus as affected by depth and duration of burial. - Weed Res. 39: 345-354. https://doi.org/10.1046/ j.1365-3180.1999.00149.x

Peters P. (2000): Tetrazolium testing handbook. Contribution No. 29. To the handbook on seed testing. - Prepared by the tetrazolium sub-committee of the Association of Official Seed Analysts. Part 2. - Lincoln, Nebraska, USA.

Peter K. \& Gandhi P. (2017): Rediscovering the therapeutic potential of Amaranthus species: A review. - Egypt. J. Basic Appl. Sci. 4(3): 196-205. https://doi.org/10.1016/j.ejbas.2017.05.001

Ranal M. A. \& Santana G. D. (2006): How and why to measure the germination process. - Braz. J. Bot. 29(1): 1-11. http://dx.doi.org/10.1590/S010084042006000100002

Rastogi A. \& Shukla S. (2013): Amaranth: A new millennium crop of nutraceutical values. - Critical Reviews in Food Science and Nutrition. 53(2): 109-125. DOI: 10.1080/10408398.2010.517876

Smith K. D., May P. B, Moore G. M. (2001): The influence of compaction and soil strength on the establishment of four Australian landscape trees. - J. Arboric. 27(1): 1-7.

Soyelu L. O., Ajayi S. A., Aluko O. B., Fakorede M. A. (2001): Varietal differences in development of maize (Zea mays L.) seedlings on compacted soils. - J. Agron. Crop Sci. 186(3): 157-166. DOI: 10.1046/j.1439-037X.2001.00467.x

Tiryaki I. (2009): Osmotic priming increases seed germination of Amaranthus caudatus L. at low temperature. - Agrochimica 53: 177-182.

Tiryaki I. \& Keles H. (2012): Reversal of the inhibitory effect of light and high temperature on germination of Phacelia tanacetifolia seeds by melatonin. J. Pineal Res. 52(3): 332-339. DOI: 10.1111/j.1600-079X.2011.00947.x

Torra J., Royo-Esnal A., Recasens J. (2016): Temperature and light requirements for germination and emergence of three Arable Papaveraceae species. Weed Sci. 64(2): 248-260. https://doi.org/10.1614/WS-D-15-00127.1 
United States Department of Agriculture (USDA) (1951): Soil survey manual. In: Agricultural Handbook No. 18. - U.S. Department of Agriculture, Washington DC, USA.

van Rensburg W. J. (2014): Cultivating pseudo-grains in South Africa. - Farmers Weekly. Available online via (http://www.farmersweekly.co.za/crops/fieldcrops/cultivating-pseudo-grains-in-south-africa/ [accessed on November 5th, 2017]. 